\begin{tabular}{|c|c|c|}
\hline & Int.J.Curr.Microbiol.App.Sci (2021) 10(09): 262-267 & \\
\hline EXCELLENT & $\begin{array}{l}\text { International Journal of Current Microbiology and Applied Sciences } \\
\text { ISSN: 2319-7706 Volume } 10 \text { Number } 09 \text { (2021) } \\
\text { Journal homepage: http://www.ijcmas.com }\end{array}$ & $\$ Q^{\circ} \otimes$ \\
\hline $\begin{array}{l}\text { EXCELLENT } \\
\text { PUBLISHERS }\end{array}$ & & \\
\hline
\end{tabular}

Original Research Article https://doi.org/10.20546/ijcmas.2021.1009.030

\title{
Develop the Value Added Products and Sensory Evaluation of Proso Millet Fresh Products
}

\author{
Swiny Sandhvi* and Vishakha Singh
} Department of Food Science and Nutrition, College of Community and Applied Sciences,
Mahrana Pratap University of Agriculture and Technology, Udaipur (Raj.), India

*Corresponding author

Keywords

Proso millet, Value added products, Sensory evaluation

Article Info

Accepted:

15 August 2021

Available Online:

10 September 2021

\section{A B S T R A C T}

Proso millet is a protein-rich grain that also contains minerals such as phosphorus and magnesium. The amount of phosphrous (206mg) and magnesium $(153 \mathrm{mg})$ in this millet is higher than in other millets. Processing such as soaking and roasting affects the mineral content and fibre, however it reduced anti-nutritional factors like phytate and tannin content. Many traditional Indian Recipes have been prepared from proso millet or blended with other cereal and legume flours to enhance the nutritional value and palatability. Development and value addition to proso millet incorporated fresh products like Proso millet chapati and kitchari. It can be concluded that sensory evaluation done on all the recipes revealed that Proso millet significantly improved their organoleptic evalutaion. Proso millet formulated chapati and kitchari was found rich in nutrients and its overall acceptability was also good.

\section{Introduction}

Millet is a high-energy crop with small seeds. Proso millet is a millet variety. It uses the least quantity of water when compared to other dietary grains. It's a resilient plant that thrives in desert conditions and rainy areas.

Proso millet is marketed as a gluten-free product that may be introduced into the diets of wheat intolerant persons. Proso millet is highly nutritious and it is good substitute for wheat and can be used to make a variety of recipes. Millets and their products are becoming less popular as a result of changing consumer habits, rapid urbanisation, the time and energy required to prepare millet-based foods, insufficient domestic structure, poor marketing facilities, processing techniques, unstable supplies, and relative unavailability of millets and their products, including flour, when compared to other foodstuffs (Balasubramanian, 2013). It can be consumed at every meal-breakfast, lunch and dinner. 
Here are some luscious recipes that can be made with Proso millet.

\section{Breakfast}

Chila, idli, dosa,

\section{Lunch/Dinner}

Proso millet vegetable kitchari, Proso millet poori, mixed millet chapathi.

Dessert

Proso millet payasam, halwa.

\section{Snacks}

Poro millet namkin, gatte, biscuits.

\section{Materials and Methods}

\section{Value added proso millet recipes}

Proso millets can be used for traditional as well as prohealth foods. Due to socioeconomic and industrial causes, food value addition has been increasingly important in the recent decade.

\section{Selection of recipes}

Here, the proso millet chappati and kitchari are made, this type of products may provide balanced nutrients. Hence, an attempt was made to explore the Value addition of proso millet in terms of this products. As a result, an investigation into the value addition of proso millet in terms of these products was undertaken.

\section{Preparation of proso millet chapatti}

\section{Method of preparation}

Take proso millet and wheat flour in bowl.
Mix both flour and salt.

Add sufficient water and knead to make a soft dough.

Heat a griddle.

Dust \& roll the dough balls to make thick chapati.

Transfer the roti on the hot griddle.

Roast the chapati till done on both sides.

Smear ghee on the top \& Serve hot.

\section{Preparation of proso millet Kitchari}

\section{Method of preparation}

Soak proso millet for 8 hours.

Properly wash proso millet and green gram dal.

Chop the carrot, green chili, tomato and coriander leaves into small pieces.

Put a spoon full ghee in cooker and heat it.

Add cumin, chopped carrot and green chills, peas, tomato, proso millet, dal, turmeric powder.

Add sufficient water and salt, cook at medium flame upto after 2-3 whistle.

Granish with coriander leaves and serve hot.

\section{Results and Discussion}

\section{Nutritive value of proso millet chapati}

In a study observed that, on the development and standardization of Proso based chapatti showed a proximate content which included 
moisture $\%$ in the range of $8.52 \mathrm{gm}$, energy content of $364.54 \mathrm{Kcal} / 100 \mathrm{~g}$, protein of 11.25 $\mathrm{g} / 100 \mathrm{~g}$, crude fiber of $5.90 \mathrm{~g} / 100 \mathrm{~g}$, ash content in the range of $3.21 \mathrm{~g} / 100 \mathrm{~g}$ and the carbohydrate content in the range of $70.16 \mathrm{~g}$.

The proximate composition of the developed proso millet Kitchari indicated an Energy $358.03 \mathrm{kcal} / 100 \mathrm{gm}$. The Kitchari also provided a good amount of protein ranging from $14.6 \mathrm{~g} / 100 \mathrm{~g}$. The carbohydrate content ranged from $69.71 \mathrm{~g} / 100 \mathrm{~g}$, fiber content was
$3.63 \mathrm{~g} / 100 \mathrm{~g}$ and fat content ranged from $2.31 \mathrm{~g} / 100 \mathrm{~g}$. The ash content was in the range of $2.44 \mathrm{~g} / 100 \mathrm{~g}$. The moisture content of the developed product was $7.31 \mathrm{~g} / 100 \mathrm{gm}$.

Sensory evaluation of the prepared products was carried out using 9 point hedonic scale. Which is 9- like extremely, 8 - like very much, 7 - like moderately, 6 - likes slightly, 5 - neither like nor dislike, 4 - dislike slightly, 3 - dislike moderately, 2-dislike very much, 1dislike extremly

Table.1 Prepration of proso millet chapatti

\begin{tabular}{|c|c|}
\hline Ingredients & Quantity \\
\hline Proso millet flours & 30gram \\
\hline Wheat flours & 20 grams \\
\hline Salt & to taste \\
\hline Water & $10 \mathrm{ml}$ \\
\hline
\end{tabular}

Table.2 Prepration of proso millet Kitchari

\begin{tabular}{|c|c|}
\hline Ingredients & Quantity \\
\hline Proso millet & $50 \mathrm{gm}$ \\
\hline Green gram dal & $10 \mathrm{gm}$ \\
\hline Turmeric powder & $2 \mathrm{gm}$ \\
\hline Cumin & $2 \mathrm{gm}$ \\
\hline Coriander leaves & $2 \mathrm{gm}$ \\
\hline Pea & $5 \mathrm{gm}$ \\
\hline tomato & $5 \mathrm{gm}$ \\
\hline Carrot & $5 \mathrm{gm}$ \\
\hline Green Chilly & $2 \mathrm{gm}$ \\
\hline Salt & to taste \\
\hline Water & $25 \mathrm{ml}$ \\
\hline
\end{tabular}

Table.3 Nutritive value of proso millet chapatti

\begin{tabular}{|c|c|}
\hline Nutrient & Mean $\mathbf{\pm S D}$ \\
\hline Moisture(g) & $8.52 \pm 0.21$ \\
\hline Ash (g) & $3.21 \pm 0.05$ \\
\hline Crude fiber(g) & $5.90 \pm 0.45$ \\
\hline Crude Protein (g) & $11.25 \pm 0.11$ \\
\hline Fat(g) & $4.23 \pm 0.61$ \\
\hline Carbohydrates(g) & $70.16 \pm 0.24$ \\
\hline Energy (kcal) & $364.54 \pm 0.31$ \\
\hline
\end{tabular}


Table.4 Nutritive value of proso millet Kitchari

\begin{tabular}{|c|c|}
\hline Nutrient & Mean \pm SD \\
\hline Moisture(g) & $7.31 \pm 0.40$ \\
\hline Ash (g) & $2.44 \pm 0.27$ \\
\hline Crude fiber(g) & $3.63 \pm 0.36$ \\
\hline Crude Protein $(\mathbf{g})$ & $14.6 \pm 0.17$ \\
\hline Fat $(\mathbf{g})$ & $2.31 \pm 0.31$ \\
\hline Carbohydrates(g) & $69.71 \pm 0.81$ \\
\hline Energy (kcal) & $358.03 \pm 0.44$ \\
\hline
\end{tabular}

Table.5 Sensory evaluation of proso millet chapatti

\begin{tabular}{|c|c|c|c|c|c|c|}
\hline & Colour & Taste & Flavor & Texture & Appearance & $\begin{array}{c}\text { Overall } \\
\text { acceptability }\end{array}$ \\
\hline T1 & $8.1 \pm 0.30$ & $8.20 \pm 0.36$ & $7.25 \pm 0.36$ & $7.81 \pm 0.65$ & $8.32 \pm 0.24$ & $8.2 \pm 0.51$ \\
\hline T2 & $8.15 \pm 0.48$ & $8.2 \pm 0.42$ & $7.4 \pm 0.98$ & $7.61 \pm 0.86$ & $8.52 \pm 0.23$ & $8.3 \pm 0.47$ \\
\hline T3 & $8.05 \pm 0.22$ & $8.3 \pm 0.25$ & $7.2 \pm 0.31$ & $7.52 \pm 0.74$ & $8.01 \pm 0.61$ & $7.36 \pm 0.22$ \\
\hline T4 & $8.0 \pm 0.45$ & $8.11 \pm 0.56$ & $7.0 \pm 0.66$ & $6.8 \pm 0.95$ & $7.6 \pm 0.55$ & $7.0 \pm 0.45$ \\
\hline
\end{tabular}

Table.6 Sensory evaluation of proso millet kitchari

\begin{tabular}{|c|c|c|c|c|c|c|}
\hline & Colour & Taste & Flavor & Appearance & Consistency & $\begin{array}{c}\text { Overall } \\
\text { Acceptability }\end{array}$ \\
\hline T1 & $9.15 \pm 0.36$ & $9.26 \pm 0.41$ & $8.67 \pm 0.30$ & $8.12 \pm 0.44$ & $8.05 \pm 0.51$ & $8.5 \pm 0.41$ \\
\hline
\end{tabular}

Fig.1

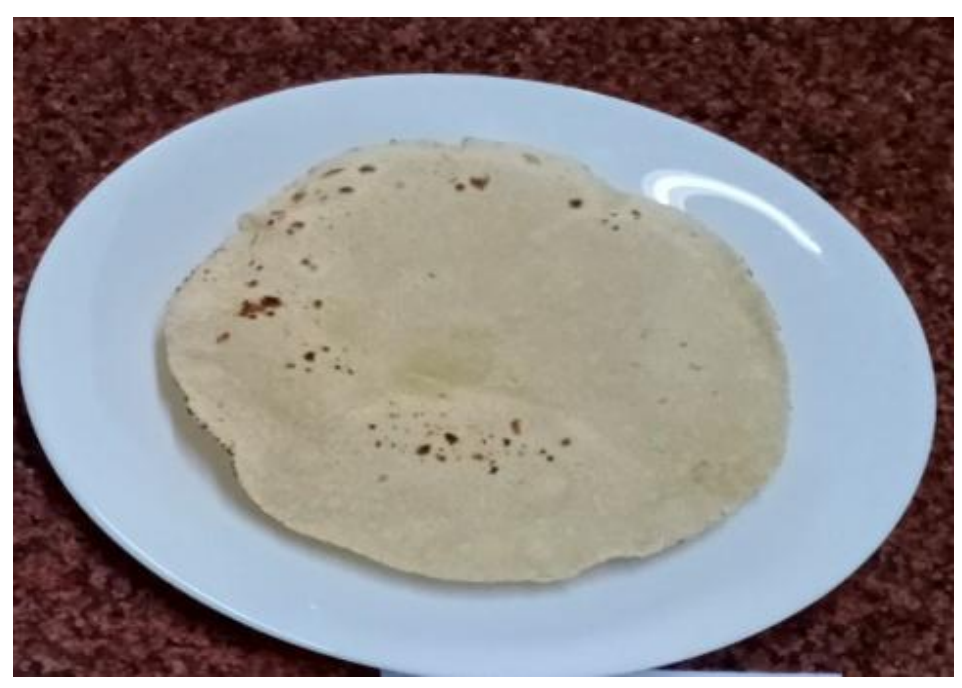


Fig.2

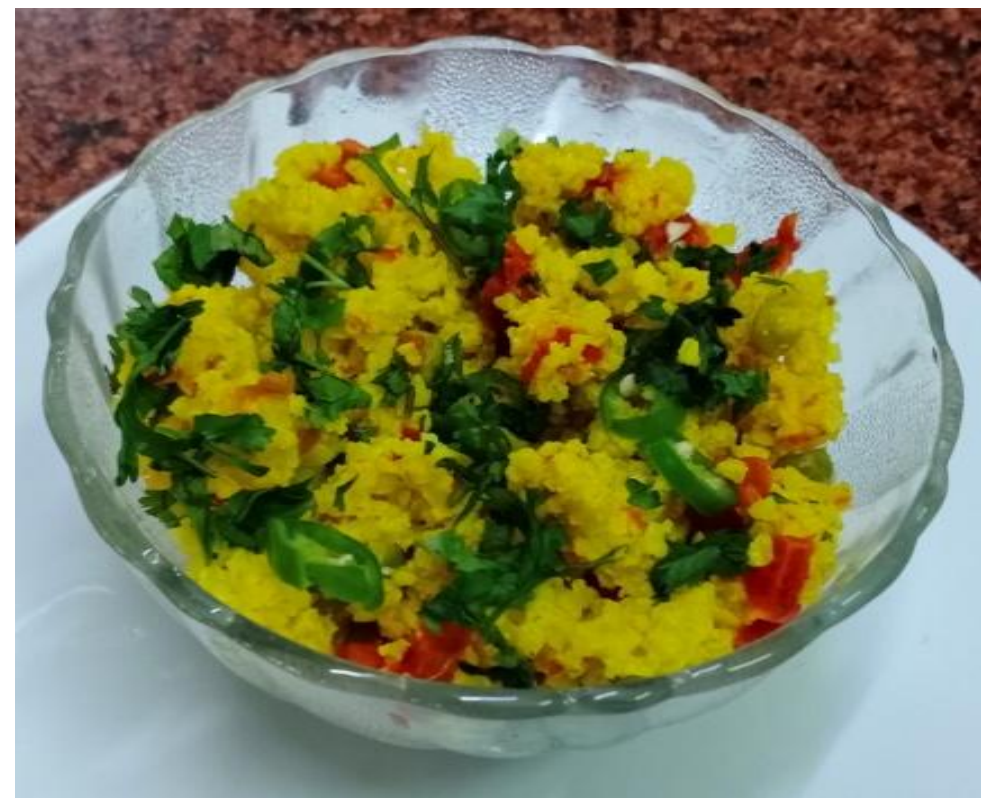

\section{Sensory evaluation of proso millet chapati}

The mean score for treatment T1, T2, T3 and T4 are $8.2,8.3,7.36$ and 7.0 respectively. The treatment T2 (8.3), T3 (7.36), and T1 (8.2) ranked among like very much to like extremely. The treatment T2 (8.3) is most accepted by the judges. So use of $30 \%$ of proso millet flour is more acceptable than the other treatment combinations Table no.6.

Table no.6 shows that Proso millet kitchari was highly acceptable with colour (9.15), taste (9.26) and Flavour (8.67), least acceptable with consistency (8.05) and overall acceptability was (8.5).

Proso millet is one the oldest grains of the country. Some millet are very popular such as ragi, jowar, bajara etc in India but proso millet not very much popular. Because people do not know about proso millet nutritional value. Proso millet is rich in protein and minerals. Millets are nutritionally good than other cereals. Proso millet incorporated products, such as proso millet kitchari and chapati, are being developed and added value to. It may be stated that sensory evaluation of all of the recipes demonstrated that proso millet improved their organoleptic rating significantly. The development and use of such value-added products will help in the increased consumption of proso millets as well as the economic upliftment of farmers, all of which will benefit human health.

\section{References}

Balasubramanian, S.2013. Processing of millet. National Seminar on Recent Advances in processing, utilization and nutritional impact of small millets.1:114.

Himaja, K. and Meera, M.(2020). Development and Nutritional Analysis of Sorghum Millet-Nut Bar. Journal of Ready to Eat Food. Vol 07 (3):39-43

Kalinova, J. and Moudry, J. (2006). Content and Quality of protein in proso millet (Panicum

Miliaceum L.) varieties. Plant Foods for Human Nutrition. 61: 45-49.

Muragod, P. P., Muruli, N. V., Siddarodha Padeppagol and Kattimani A. (2019). 
Develop the Value Added Products and Evaluate the Storage Quality of Kodo Millet Grains Products. Int. J. Pure App. Biosci. 7 (1): 97-107

Santosh, Kumar. K., Dattamazumdar, S. and
Renu, R.(2018). Development of Millet Based Foods Enriched with Peanuts and Pulses. Int.J.Curr.Microbiol.App.Sci. $\quad 7(4)$ : 2903-2914

\section{How to cite this article:}

Swiny Sandhvi and Vishakha singh. 2021. Develop the Value Added Products and Sensory Evaluation of Proso Millet Fresh Products. Int.J.Curr.Microbiol.App.Sci. 10(09): xx-xx. doi: https://doi.org/10.20546/ijcmas.2021.1009.xx 